Vesna Janjić ${ }^{1}$

Jasmina Bogićević

Bojan Krstić ${ }^{3}$

University of Nis, Faculty of Economics
ORIGINAL SCIENTIFIC ARTICLE doi:10.5937/ekonomika1902013J Received: March 05, 2019 Accepted: May, 08, 2019

\title{
KAIZEN AS A GLOBAL BUSINESS PHILOSOPHY FOR CONTINUOUS IMPROVEMENT OF BUSINESS PERFORMANCE
}

\begin{abstract}
Today, numerous tools can be used in the production and other phase of the value chain with the aim of increasing operational efficiency and quality of products. However, the Kaizen can be understood as one of the basic lean techniques. Continuous improvement applied through Kaizen is a key element of Japanese management and the source of competitiveness. The benefits of an effective program of continuous improvement are reflected in cost efficiency, waste reduction and product quality improvement. Taught by Japanese success, many companies have adopted Kaizen as a technique for improving production efficiency and achieving business excellence. Despite the Kaizen implementation has led to improved performance in many companies and its application is widespread around the world, many problems and difficulties in its implementation are observed outside Japan. The process of transferability of Kaizen is influenced by many factors whose significance and intensity vary depending on the country in which it is applied. Hence, although Kaizen is very simple at first glance, it is a complex process that needs to be adapted to the specificities of the environment, taking into account numerous influential factors.
\end{abstract}

Key words: continuous improvement, Kaizen, lean, technique

JEL classification: M21, M41

\section{КАИЗЕН КАО ГЛОБАЛНА ПОСЛОВНА ФИЛОЗОФИЈА ЗА КОНТИНУИРАНО УНАПРЕЪЕЊЕ ПОСЛОВНИХ ПЕРФОРМАНСИ}

\footnotetext{
Апстракт

Данас се у оквиру производне фазе ланца вредности могу применити бројни алати за повећағе оперативне ефикасности и квалитета производа. Међутим, Каизен се може схватити као једна од основних леан техника. Континуирано побољшање омогуе́но захваљујући Каизен концепту представља

${ }^{1}$ vesnajanjic64@gmail.com

2 jasminabogic@ptt.rs

${ }^{3}$ bojan.krstic@eknfak.ni.ac.rs
} 
кључни елемент јапанског менацмента и извор конкурентности. Предности једног ефективног програма континуираног побољшања огледају се у трошковној ефикасности, смањењу отпада и побољщиьу квалитета производа. Поучене јапанским успехом, многе компаније усвојиле су Каизен као технику побољшања производне ефикасности и остварења пословне изврсности. И поред тога што је имплементачија Каизена довела до побољиаға перформанси у многим компанијама и ито ьегова примена има светске размере, уочени су бројни проблеми и потешкоће у спровођењу ван Јапана. На процес трансфера примене технике Каизена утичу бројни фактори чији се значај и интензитет разликује у зависнови од земље у којој се ова техника примењује. Иако се на први поглед Каизен чини једноставан, ради се о комплексном процесу юегове примене, који треба прилагођавати специфичностима окружења у коме се примењује уз уважавање бројних утицајних фактора.

Кључне речи: континуирно побољшање, Каизен, леан, техника

\section{Introduction}

A new turbulent business environment has created a new scenario for the competitive development of companies in the $21^{\text {st }}$ century. In order to survive and successfully compete in a market where consumers focus on high product quality, low price, availability, companies have to use the best management practices, strategies and tools. The results of the long-standing research of economic theory and management practice show that continuous improvement has great benefit in the purpose of reaching competitive advantages. Namely, the continuous improvement is considered as a key for achieving excellence in production and other business processes. In continuous improvement many companies found a way to effectively and efficiently manage various and complex business processes, such as procurement, delivery, new product development and others. There is no doupt that the continuous improvement has become a very relevant factor of sustainable business success. Numerous theoretical considerations in the contemporary literature and practical experience provide many evidences of better company performance based on successful implementation of the continuous improvement as a management tool and philosophy (Quesada-Pineda, Madriga, 2013, 1). Latterly, in the new literature and best business practice, there are the most commonly discussions about the following concepts: lean production, six sigma, boundary theory, quality control, Kaizen etc.

Kaizen is a Japanese management technique that is focused on improvements through various small movements, steps and ideas to increase labour productivity, business efficiency, product and service quality and other operational and financial performance. After useful implementation in a numerous Japanese companies, this technique has sparked great interest among academic researchers and practitioners in the sense of achieving high-quality outputs with minimal efforts. Kaizen became a popular and applicable management tool in other countries around the world. Doubtless, it has gained the status of a global process. However, despite its popularity, the implementation of Kaizen in many companies worldwide, has not led to the expected results and faces many operational challenges. 
The subject of theoretical research in this paper is to point out the significance of Kaizen in the process of continuous performance improvements in business organization. The aim of this paper is to examine the possibilities of Kaizen implementation at the international level and to highlight the factors that influence the success of this transfer process. The paper consists of four parts. The first part deals with the role of Kaizen in the process of continuous improvement and the effects of its application. The second part analyzes the process of transferring Kaizen outside the Japan. The third part is devoted to factors that influence the transferability of Kaizen. The experiences of countries regarding the use of Kaizen and the factors that influence its success are given in the fourth part of the paper.

\section{The continuous improvement by using the Kaizen}

Investigating the problems of continuous improvement, many authors have written about the occurrence of Kaizen, as a key element of management in Japanese companies. They have presented Kaizen as one of the basic elements of the concept of lean production and total quality management. Kaizen has Japanese origin and means the process of continuous and incremental improvement of overall activities in the production, although it does not exclude the possibility of its application in other areas. It represents one of the sources of competitiveness of Japanese companies. They rely on modern technology for achieving high product quality and productivity with the aim of Kaizen as business philosophy and management technique. Due to the pronounced competition, Kaizen received an international recognition. Kaizen was implemented in companies worldwide to help them to improve their performance, based on continual improvement of all aspects of the operation. Inspired by Japanese success, many companies in developed, developing and underdeveloped countries adopt the business Kaizen philosophy to improve production values (Bwemelo, 2014, 79-91).

In its original term, Kaizen is a combination of two Japanese words ("kai" and "zen") and means improvement or change for the better and focuses on continuous improvement throughout the company (Dhongade et al., 2013, 57). Kaizen achieves improvement through small steps and continuously, unlike the innovations that are dramatic and impressive, and require investment in new technology and equipment. It implies less radical changes which are the result of innovative ideas that take place over time without the investment of huge capital (Kumar et al., 2017, 147). So, Kaizen and innovations are used to achieve improved operating procedures and performance. The key to continuous improvement in the Kaizen is in the small innovations and creative ideas of employees whose results are often subtile and barely visible in the short term. In other words, the Kaizen refers to small changes. Innovations relate to comprehensive modifications caused by large investments. Kaizen relates to continuous accumulation and aggregation of improvement activities (gradual approach). Kaizen is not related to rapid and large changes inherent in innovative technology breakthroughs (great leapforward approach) (Ramezani, Razmeh, 2014, 45). Actually, it emphasizes a series of continuous improvements and small incremental steps that can be used at all levels in the organization. Its application requires simple techniques and conventional methods, and does not require sophisticated technology or the latest technological achievements. 
Kaizen emphasizes a continuous search for new possibilities for achieving goals in the easiest way and at the lowest cost (Titu, 2010). The most important assumption of successful implementation of Kaizen is the reliance on common sense and the active involvement of all employees in the company (managers, experts, controllers and direct executors) in order to strengthen morale through teamwork, and more productive and more economical use of resources in a company. Basically, Kaizen is a very simple idea that emphasizes the importance of employees and their ability to carry out the process of continuous improvement. The main thing that companies need to know about implementing a continuous improvement program is how the smallest idea can lead to the greatest results (Jarial, 2012, 227). As executors are directly referred and connected to activities that are carried out in the production process, the greatest number of ideas for improvements come from the executors. Hence, the efficient implementation of Kaizen emphasizes the importance of adequate training of employees. The Kaizen becomes attractive because it enables companies to maximize their human or work productivity potential and enjoy numerous benefits (Vent et al., 2016, 695).

The effects of its application result in improving productivity level, quality and efficiency, lower costs, eliminating of losses, enhance job security, quick delivery of products and greater customer satisfaction. In short, Kaizen is an inexhaustible source for achieving business excellence (Titu, 2010). Since the benefits of implementation come gradually and the effects are usually felt over a longer time, the top management are responsible for the successful implementation. Therefore, improvement is considered as one of the most important managerial activities (Suárez-Barraza, Miguel-Dávila, 2008, 293). There is almost a unique attitude that Kaizen is an uninterrupted process in its nature, in the sense of possibilities to be a more efficient (Jignesh et al., 2014, 812).

Kaizen, understood as a new business philosophy, was introduced and accepted in Japan after the Second World War as a part of the business culture. It spread rapidly among the Japanese companies, and became known as the Japanese model of managing the business organization. Its development line (from 1950 to the present) has continued, in particular, by expansion in Japan first and later in other parts of the world (in developed, developing and underdeveloped countries). Thus, it has received the epithet of an international process with all the accompanying problems.

\section{The process of Kaizen transferring - the essence, problems and phases}

The international process of Kaizen transfer has become inevitable for several reasons, especially due to the expansion of Japanese business activities through the great number of multinational companies, as well as the requirement for better quality and cheaper products. The answer to the question about the experiences with the use of Kaizen outside Japan and the success of the company's achievements requires a deeper analysis. Namely, its implementation depends on the country in which the Kaizen was transferred, as well as a number of factors. On the basis of theoretical and practical research of numerous authors, there were various conclusions. Some consider that portability of Kaizen outside of Japan is possible, but in order to increase the chances of success of transfers, the following conditions need to be met: 
a) Clear orientation of employees for unconditional acceptance of Kaizen;

b) Commitment of employees to the long-term sustainability of the company;

c) Free flow of information both vertically and horizontally;

d) Authorization of employees and the skills necessary for decision making;

e) Pragmatic orientation;

f) Employees should be oriented to the process and results (Desta, 2012).

According to Aoki, the basic prerequisite for spreading Kaizen beyond of Japan is the implementation of the basic principles of the Kaizen business philosophy, above all: consumer focus, continuous improvement, accepting the existence of a problem, team building, self-discipline development, constant information feedback to employees and the promotion of employees' development and training (Aoki, 2008, 520-523). On the other hand, some researchers argue that practical application is a part of the Japanese culture and it is difficult to transfer to abroad. The failure to implement Kaizen in many foreign companies is attributed to the fact that they did not accept the Japanese way of corporate governance based on the assumption that what is done in Japan must be uniformly applied to other countries (Shaari, 2010, 405).

Regardless of all the difficulties and problems with the application of Kaizen outside Japan, the international transfer of Kaizen is not a one-off act, but a process that takes place through several phases. There are several models that include the transfer of Kaizen in the literature on the international transfer of the Japanese management system, technology and know-how. These are the phase model and the process model.

The phase model for the transboundary transfer of the Japanese industrial management system includes four phases. The first phase involves the establishment of a local branch and involves familiarizing employees with operational management techniques. The application of production techniques, management techniques and knowledge management is the second phase. Japanese experts train managers and engineers. The third phase relates to adapting the implemented system of management and knowledge to the local environment. The fourth phase refers to the integration of control systems. Local managers and engineers improve production and management techniques to respond to the needs of the local environment (Yokozawa et al., 2011, 40). Gilbert and Cordey-Hayes (1996) developed the process model of knowledge transfer in order to understand the ability of companies to innovate and successfully implement organizational changes. This model includes the following five phases: a) acquiring knowledge; b) communication and transfer of acquired knowledge; c) application of acquired knowledge; d) acceptance of knowledge by individuals in an organization; and e) knowledge becomes crucial.

Szulanski (2000) represents a knowledge transfer model in four phases: 1) the initial phase; 2) implementation, 3) improvement and 4) integration. Miles (1995) identifies five phases: 1) choice of technologies, 2) technology transfer channels, 3) technology adaptation, 4) technology integration and 5) implementation. The presented models suggest that there are several stages in the international transfer of the Japanese management system, including the Kaizen.

Number of stages could be reduced by the comparative analysis to the following: preliminary, communication, application and integration. The preliminary phase begins when the need for transfer of Kaizen practice is identified and includes a feasibility study 
and needs assessment. In other words, this phase includes preparatory activities in the decision-making process whether or not a Kaizen transfer should be carried out (Szulanski, $2000,12)$. The main initiator for the implementation of this phase is the parent company in Japan. The communication phase begins when the decision to transfer Kaizen is made. The role of Japanese trainers as the main actors at this stage is to train local engineers, executives and employees. On the other hand, employees from the branch are sent to the parent company for training. In case of Kaizen transfer, this phase ends when local operators improve the Japanese production processes and techniques. Operators think of improvement only when they master the standard operating procedure. The application, as a third phase, begins when management accepts the use of Kaizen and consists of three mutually dependent cycles. The first cycle involves actions that relate to the decision to adopt a lean paradigm (e.g. to build a vision, encourage learning process, etc.). The second cycle is long-term and both the environment and necessary conditions for successful transformation are formed (e.g. to create an implementation team, develop a strategy, and set operational goals). The short-term cycle is the third one and it implies detailed implementation through planning, execution and monitoring. Japanese coaches and employees of the Kaizen transferring company are the main players in implementing this phase (Yokozawa, 2011, 41). Integration, as the last phase of the Kaizen transfer process, begins when local managers take the initiative of Japanese leaders and when employees begin to realize the process of continuous improvement (Szulanski, 2000, 12).

On the basis of the previous one, it is noted that the transfer of Kaizen is a process that takes place in several not easy to implement phases, because the Kaizen international transfer is influenced by numerous factors, and the literature in this field points to the key success factors in the implementation of continuous improvement.

\section{The influence of critical factors on Kaizen implementation transfer}

Many companies, taught by Japanese success, have adopted Kaizen as the most effective tool for improving productivity and product quality by better internal organizational (work and managerial) processes. The application of Kaizen has become more and more popular (Shahab et al., 2007) around the world, and it gets an epithet of the global process. However, despite its popularity and organizational potential, there are many factors that influence the effectiveness of the Kaizen program in developed and developing countries, as well as underdeveloped countries.

Studying the problem of global Kaizen implementation, the researchers came to the conclusion that the percentage of Kaizen implementation in many companies is high, but the results of its implementation are unsatisfactory. Of the 3000 surveyed industrial companies, $90 \%$ implemented Kaizen, but only $10 \%$ of them achieved satisfactory success (Rink, 2005). The results of the survey conducted in 2010 on a sample of 360 companies in Spain and Mexico indicate that 33\% of companies accepted the Kaizen program, but the success is expressed in small traces of continuous improvement due to, first of all, poor coordination between direct executives and management and employee resistance changes (Hailu et al., 2017, 589) The recent research has confirmed and found that there is a problem with the international transfer of Kaizen in $80 \%$ of Japanese companies. It leads to conclusion that there are problems in the Kaizen transfer outside Japan despite 
simple business philosophy and the application of common sense (Yokozawa et al., $2010,8)$. On the basis of this, it also can be concluded that the international transfer of Kaizen is not easy to achieve. Unlike the domestic implementation of Kaizen, the transfer of Kaizen to other countries includes issues relating to the diversity of national economies and national and business cultures. The authors believe that Kaizen, as a business philosophy applied in Japan, cannot be automatically applied, and transferred without adaptation to other countries and cultures (Shaari, 2010, 405).

It has been discovered that companies in many countries have faced the problems of gaining the advantages (Suares-Barraza et al., 2011, 63) and the problems of applying and maintaining improvements in their business, but little is known about the reasons. So, the question arises what are the main critical success factors of Kaizen? The main objective of studying these factors is how well-known and high-quality techniques, such as Kaizen, are implemented in companies in order to make the positive outcome. The other reason is to prevent executives from rejecting the application of Kaizen program in its initial or any later phases.

Based on relevant literature and conducted research on companies that have applied Kaizen, common factors have been identified for most countries. They can be systematized as follows (Anh et al, 2015, 66; Garcia et al., 2013, 539):

- Supreme dedication of leaders,

- Organizational culture,

- Employee initiative,

- Employee awards and recognitions,

- Training and introduction of employees with Kaizen tools and techniques and

- Kaizen event and team design.

The management commitment to the Kaizen implementation is considered to be the main factor of success. In fact, managers can be apathetic, managers who are watching and managers who support the improvement process. The most desirable role for managers to implement Kaizen is their support and commitment. The top management is personally interested in the continuous improvement program success and plays a central role in Kaizen implementation. Therefore, strong management support for redefining responsibilities is the key factor for the Kaizen implementation.

The success in the Kaizen implementation depends in large part on organizational culture, and companies must first of all make radical changes towards the creation of a special value system, in which every kind of loss and inefficiency is eliminated. All Kaizen programs implemented in Japan had one of the key common prerequisites, i.e. to attract workers to accept innovations and master their resistance to change (Masaaki, 1986). The attracting of all employees to participate in the process of continuous improvement requires a good organizational culture, which includes a set of values and behaviours in the company.

Employee Initiative implies a form of individual behaviour performing activities outside contracted works. Generally speaking, an action taken by an individual as a personal initiative provides an opportunity for improvement, termination of the status quo and creating an atmosphere for finding a problem. The lack of employee dedication in the implementation of Kaizen is one of the main reasons why many programs of improvement, even those who are initially successful, fail at the end (Keating et al., 1999, 129; Chhikara, Gahlyan, 2017, 10) 
Employee rewards can influence the activities of Kaizen. However, researchers felt that a merit-based award was not good for improving product quality. The ability of employees to find a solution to the problem of product quality is failing in companies with remarkable awards and recognitions. Getting to know the public with the improvements achieved is more valuable than the economic incentives of employees. Congratulations to employees when they deserve are also part of the award and recognition. Japanese companies set the acknowledgments of team members and workers on the wall in their workplaces and are symbolic in nature (Garcia et al., 2013, 541).

For the effective participation of employees in Kaizen activities, their training and getting acquainted with tools and techniques for continuous improvement are necessary. Staff training must be practical in nature and tailored to the work they do. Kaizen activities are supported by numerous tools and techniques, such as problem-solving techniques, quality control techniques, and others whose use involves employee training and education. Otherwise, insufficient training, lack of skills for solving problem are the main factors of unsustainability of the continuous improvement process.

The Kaizen team plays a key role in the continuous improvement of the company (Sundar et al., 2014, 1881). The greater the competence of the Kaizen team, the greater the chances of success of the continuous improvement of the larger. The Kaizen team should be homogeneous, composed of workers from all departments, with the largest number being from the production, maintenance and quality sectors. By forming a cross-functional multifunctional team, the implementation process becomes much more reliable (Chhikara, Gahlyan, 2017, 8).

Studying the international transfer of Kaizen, Yokozawa, Steenhuis and de Bruijn (2011) concluded that there were many factors that influence every phase of the Kaizen transfer process that could be underlined under the aforementioned, but there are additional ones such as: the willingness of young operators to accept innovations, to hire young people immediately after schooling, to train workers in Japanese companies, the problem of hiring appropriate workers in certain industrial branches and location of activities, the problem of employees who do not fit into Kaizen culture.

Based on a brief insight into the critical success factors of the Kaizen, it can be concluded that there are several critical factors, which are not universal and differ in importance, so it is necessary to take into account the specifics of the business of the country in which the Kaizen is transferred in their identification. The fact is that the success of Kaizen transferring abroad depends on the degree of compatibility between the culture of Japanese companies and the national culture of the host country. In order to achieve the greatest success in the implementation of Kaizen it is necessary to adapt its practical application to the culture of the host country, and it can be concluded that it has not been and there will not be in the future a single model that will be uniformly applied everywhere (Anh et al., 2011).

\section{The experience in international Kaizen implementation transfer}

Through its multinational companies and international cooperation Japan has tried to transfer the Kaizen business philosophy in order to improve quality and productivity in other countries with different cultures and business environments. Over time, the 
Kaizen has become internationalized and institutionalized in many countries on almost all continents, and has become a life philosophy and internationally recognized as a solid strategic instrument for adapting to global competition by improving productivity and quality (Bwemelo, 2014, 79). Despite the international diffusion of the Kaizen concept, many researchers have pointed to difficulties in its implementation in companies outside of Japan.

A survey conducted in companies in Ciudad Juarez, Mexico, aimed to examine what are the main critical factors for the success of Kaizen (Garcia et al., 2013, 539). Since the literature found a number of factors, even nineteen, the authors intended to identify factors that are specific to Mexican companies. The results showed seven major critical success factors for Kaizen, which have been identified in other countries, but of varying importance and significance. Training and education of employees are the first, followed by communication between teams and managers, documentation and evaluation of projects, integration and rewards of workers, acceptance of changes and improvements, management commitment and customer focus. The research was carried out in Mexican companies of the Toluca-Lerma industrial cluster with similar results (Suares-Barraza et al., 2011). Based on the analysis of the surveyed companies, the first impression is that there is a small percentage of the use of Kaizen in Mexico, and the second is that improvements have been made only in the traces affected by the mentioned factors.

Yokozawa and Steenhuis (2013) have focused their research on transfer Kaizen between the two regions, i.e. on transfer Kaizen from Japanese companies to Europe. The study focuses on the use of Kaizen in the Netherlands, because in the period between 2003 and 2009, Japan invested most in this country. This study includes 15 Japanese companies' affiliates with the aim to examine specific factors and their impact on the Kaizen transfer process in the Netherlands. The results of the research indicate that there are two factors at the national level that affect the transfer of Kaizen, which are the degree of discipline and the commitment of employees. These factors are considered to be limiting the transfer of Kaizen into this country.

Bearing in mind that Vietnamese culture considerably differs from Japanese one, the study was conducted in 124 Vietnamese production companies during 2011-2012 with the aim of examining whether national and organizational culture influences the use of Kaizen and, therefore, performance (Anh et al., 2015, 66). Findings show that there is a positive correlation between the application of Kaizen and culture in relation to the performance of companies in Vietnam, and it is proposed to adapt effectively and flexibly the Kaizen practice to local culture in order to improve performance and achieve a competitive advantage. At the same time, other surveys (Yokozawa, Steenhuis, 2013) confirmed that it is easier to transfer Kaizen to Southeast Asian countries, like Vietnam, than to European countries because the employees are more obedient and disciplined.

Economic growth, expressed as a gross domestic product, an average of $11 \%$ a year has been recorded in Ethiopia in the last few years. The industrial sector has also grown in the last four years from $10.30 \%$ to $14.3 \%$. What is alarming about Ethiopia's economy is that the manufacturing sector is participating in the gross domestic product from $4.4 \%$ to $4.6 \%$, which is less than other countries with similar income levels. The slow development of the private sector, poor quality control and low productivity are the main obstacles to promote exports and attract domestic and foreign investment. 
The Peacock Shoe Manufacturing Company has implemented Kaizen philosophy to improve its competitiveness and exports, realized significant improvements, but at the same time faced challenges in its application. The research carried out in this company was focused on identifying critical success factors in the Kaizen implementation and maintenance. The results of the survey show that there are eight key factors for Peazock Kaizen success, sorted by importance: preparation (education and training - 16.056\%), control of process $(10.286 \%)$, planning $(9.996 \%)$, implementation (problem solving $9.157 \%)$, effective leadership (8,525\%), continuous evaluation $(8,253)$, awards and awards (7,369\%) and employee attitudes (7,298\%). Without entering into a deeper analysis of each individual factor, we cannot conclude that the management of this company should focus primarily on employee training and education, which indicates their significant and important role in implementing the continuous improvement process (Hailua et al., 2017, 585-600).

There is no similar research in the Republic of Serbia. This does not mean that the implementation of Kaizen in Serbian companies does not exist. The reasons is the economic environment in the Republic of Serbia, characterized by a transition, unfinished ownership, organizational and managerial transformation, the tendency to engage in European and global economic flows. This moments are the basis for adopting the market criteria for the application of new business philosophies, tools and techniques that are needed for the continuous improvement.

\section{Conclusion}

The results of numerous studies have found that Kaizen is rated as an effective strategy for improving performance and mechanisms for improving the organization and working environment. It has proven to be an effective tool for changing the work culture, working methods and work experience. From the innovation perspective, the Kaizen is conceived as the accumulation of small, mutually independent incremental process innovation accepted by workers, work teams and their leaders. The expected effects and ease of use of Kaizen influenced the willingness of companies to accept and use it in their operation. Kaizen has become almost a global activity distributed to many countries by the multinational companies and their employees. It has become popular not only in the manufacturing sector, but also in the service one. For business practice, which offers companies great opportunities for continual improvement and numerous benefits from the implementation of Kaizen, it is surprising that, in addition to the high percentage of the application of this simple method and technique and its prevalence of almost all continents, the results are not satisfactory or even equally important.

Research has revealed a number of challenges that companies face in the Kaizen feasibility in practice. The results of the survey, conducted in a large number of enterprises more or less on all continents, indicate a number factors that positively or negatively affect every phase of the Kaizen transfer beyond the Japan. The most common are the factors related to managerial commitment, organizational culture, employee initiatives, team management experience, awards and recognitions, employee training, as well as some specific ones. All of these factors indicate difficulties in this kind of effort implementation and maintenance over time in the cultural work environment of other 
countries. The intensity and importance of these factors are different. Therefore, transfer of Kaizen is very problematic beyond the boundaries of Japan.

Regardless of the number and specificity of the factors affecting the success of Kaizen's transferability, it has been adopted a unified attitude that managerial commitment is the key to successful implementation of Kaizen. This factor has a direct and positive impact on the professional development of employees, benefits and profit for the company (Vento et al. 2016, 707). Therefore, it can be said that managers play a key role in the effective Kaizen implementation, especially in the planning phase. In order to achieve the results offered by Kaizen, training of employees must be adequately planned. The lack of appropriate training and professional development of employees negatively affects the continuous improvement in production processes. In addition, the importance of organizational culture and financial satisfaction, as well as an adequate reward system, should be added as no less important factors.

All around the world companies can apply the Kaizen methodology and achieve an outstanding competitive advantage and a high level of operational excellence. The basic prerequisite for Kaizen proper application is its reinterpretation, which means the adaptation to the local culture of the country to which it is transferred because of the incompatibility between the Japanese culture and the national culture of the host country. It can be concluded from this that there is no universal model for the Kaizen transfer.

\section{References}

Hailua, H., Kedirb, A., Bassab,G., Jilchac, K. (2017). Critical success factors model developing for sustainable Kaizen implementation in manufacturing industry in Ethiopia, Management Science Letters 7 (12), 585-600.

Anh, P.C., Yen, T.T.H., \& Matsui, Y. (2015). Empirical Study on Transferability of Kaizen Practices in Vietnamese Manufacturing Companies, Asian Social Science; Vol. 11, No. 4, 65-76.

Yokozawa, K., Steenhuis, H.J. (2013). The influence of national level factors on international Kaizen transfer, An exploratory study in The Netherlands, Journal of Manufacturing Technology Management, Vol. 24, No. 7, 1051-1075.

Garcia, L. J., Rivera, G. D., \& Iniesta, A. A. (2013). Critical success factors for Kaizen implementation in manufacturing industries in Mexico, The International Journal of Advanced Manufacturing Technology, 68 (1-4), 537-545.

Bwemelo, G. (2014). KAIZEN as a Strategy for Improving SSMEs' Performance: Assessing its Acceptability and Feasibility in Tanzania, European Journal of Business and Management, Vol. 6, No. 35, 79-91.

Anh, P. C., Jing, Z., \& Matsui, Y. (2011). Empirical study on transferability of Kaizen practices. In The $11^{\text {th }}$ International DSI and the $16^{\text {th }}$ APDSI Joint Meeting, Taipei, Taiwan, July, 12-16.

Yokozawa, K., Steenhuis, H.J., Bruijn, E.J. (2011). Process of international Kaizen transfer in the Netherlands, The Journal of Japanese Operations Management and Strategy, Vol. 2, No. 1, 38-57. 
Chhikara, N., Gahlyan, A. (2017). Kaizen Implementation for Improving Productivity and Quality in Manufacturing Industry: A Case Study, International Journal of R\&D in Engineering, Science and Management, Vol. 6, Issue 3, 1-14.

Sundar, R., Balaji, A., \& Kumar, R. S. (2014). A Review on Lean Manufacturing Implementation Techniques, Procedia Engineering, 97, 1875-1885.

Keating, E., Oliva, R., Repenning, N., Rockart, S., \& Sterman, J. (1999), Overcoming the improvement paradox, European Management Journal, 17 (2), 120-134.

Masaaki, I., Kaizen (1986). The Key to Japan“s Competitive Success, USA, New York.

Suáres-Barraza, M.F., Castillo-Arias, I., Miguel-Dávila, J. (2011). La aplicación del Kaizen en las organizaciones mexicanas, Un estudio empírico, Revista journal, Vol. 5 No. 1, 60-74.

Shaari, J. A. N. (2010). Barriers to Implement TQM in Japanese Way: A study of Companies in Malaysian, International Review of Business Papers, 6 (5), 400-410.

Yokozawa, K., Steenhuis, H. J., \& de Bruijn, E. J. (2010). Recent experience with transferring Japanese management systems abroad. Journal of Strategic Management Studies, 2 (1), 1-16.

Rink, J. (2005). Lean can save American manufacturing, Retrieved from https://www. reliableplant.com/Read/330/lean-manufacturing-save.

Shahab, A.M., Lu, L.B., Tian, Y.Z.,Sun, X.L., (2007). Continuous Improvement Practices in Asian Developing Countries A Comparative Analysis between Chinese \& Pakistani Manufacturing Industry, 2007 International Conference on Management Science \& Engineering (14th), August 20-22, Harbin, P.R.China.

Szulanski, G. (2000). The process of knowledge transfer: A diachronic analysis of stickiness, Organizational behavior and human decision processes, Vol. 82, No. 1, 9-27.

Miles, D. (1995). Constructive change: Managing international technology transfer, Geneva, International Labour Office.

Gilbert, M., Cordey-Hayes, M. (1996). Understanding the process of knowledge transfer to achieve successful technological innovation, Technovation, Vol. 16, No. 6, 301-312.

Aoki, K. (2008). Transferring Japanese Kaizen activities to overseas plants in China, International Journal of Operation and Production Management, 28(6), 518-539.

Desta, A. (2012). The Transferability of the Japanese Kaizen Management Techniques: Lessons for Ethiopia, National Graduate Institute for Policy studies (GRIPS), Tokyo.

Jignesh, A.B., Darshak, A.D., Rohit, M.P. (2014). The Concept \& Methodology of Kaizen A Review Paper, International Journal of Engineering Development and Research, IJEDR, Vol. 2, Issue 1, 812-820.

Suárez-Barraza, M.F., Miguel-Dávila, J.A. (2008). Encontrando al Kaizen: Un análisis teórico de la Mejora Continua, Pecvnia, 7, 285-311.

Titu, M.A. (2010). Applying the Kaizen Method and the 5S Technique in the Activity of Post-Sale Services in the Knowledge-Based Organization, Proceedings of the International Multi Conference of Engineers and Computer Scientists 2010, Vol. III, IMECS 2010, March 17-19, Hong Kong. 
Vento, M.O., Alcaraz, J.L.G., Macías, A.A.M., Loya,V. M. (2016), The impact of managerial commitment and Kaizen benefits on companies, Journal of Manufacturing Technology Management, Vol. 27, No. 5, pp. 692-712.

Jarial, S.K. (2012). Performance Improvements of Sheet Metal Industry using Kaizen A Case Study, International Journal of Current Engineering and Technology, Vol. 2, No.1, 227-230.

Ramezani, A., Razmeh, A.P. (2014). Kaizen and Kaizen Costing, Academic Journal of Research in Business \& Accounting, Vol. 2, No. 8, 43-52.

Kumar, S., Dhingra, K.A., Singh, B. (2017). Implementation of the lean-Kaizen approach in fastener industries using the data envelopment analysis, Facta Universitatis, Vol. 15, No 1, 145 - 161.

Dhongade, P., Singh, M., \& Shrouty, V. (2013). A Review: Literature Survey for the Implementation of Kaizen, International Journal of Engineering and Innovative Technology, 3 (1), 57-60.

Bwemelo, G. (2014). KAIZEN as a Strategy for Improving SSMEs' Performance: Assessing its Acceptability and Feasibility in Tanzania, European Journal of Business and Management,

Vol. 6, No. 35, 79-91.

Quesada-Pineda, H.J., Madriga, J. (2013). Sustaining Continuous Improvement: A Longitudinal and Regional Study, International Journal of Engineering Business Management, Vol. 5 (43), 1-13. 